\title{
Estimation of the net energy requirement for maintenance in broilers
}

\author{
Wei Liu', Chang Hua Lin', Zheng Ke Wu', Guo Hua Liu', Hai Jie Yan ${ }^{1}$, Hua Ming Yang ${ }^{2}$, and Hui Yi Cai ${ }^{1}$ *
}

\begin{abstract}
* Corresponding Author: Hui Yi Cai
Tel: +86-1082106077, Fax: +86-1082106077,

E-mail: caihuiy@caas.cn
\end{abstract}

'The key laboratory of feed biotechnology of the Ministry of Agriculture, Feed Research Institute, Chinese Academy of Agricultural Sciences, Beijing 100081, China

2 Jilin Academy of Agricultural Sciences, Changchun 130124, China

Submitted Jun 22, 2016; Revised Aug 17, 2016; Accepted Oct 4, 2016
Objective: The net energy requirement for the maintenance $\left(\mathrm{NE}_{\mathrm{m}}\right)$ of broilers was determined using regression models by the indirect calorimetry method (ICM) or the comparative slaughter method (CSM).

Methods: A $2 \times 4$ factorial arrangement of treatments including the evaluation method (ICM or CSM) and feed intake ( $25 \%, 50 \%, 75 \%$, or $100 \%$ of ad libitum recommended) was employed in this experiment. In the ICM, 96 male Arbor Acres (AA) birds aged d 15 were used with 4 birds per replicate and 6 replicates in each treatment. In the CSM, 116 male AA birds aged $d 15$ were used. Among these 116 birds, 20 were selected as for initial data and 96 were assigned to 4 treatments with 6 replicate cages and 4 birds each. The linear regression between retained energy (RE) and metabolizable energy intake (MEI) or the logarithmic regression between heat production (HP) and MEI were used to calculate the metabolizable or net energy requirement for maintenance $\left(\mathrm{ME}_{\mathrm{m}}\right)$ or $\mathrm{NE}_{\mathrm{m}}$, respectively.

Results: The evaluation method did not detect any differences in the metabolizable energy (ME), net energy (NE), and NE:ME of diet, and in the MEI, HP, and RE of broilers. The MEI, $\mathrm{HP}$, and RE of broilers decreased $(\mathrm{p}<0.01)$ as the feed intake decreased. No evaluation method $x$ feed intake interaction was observed on these parameters. The $\mathrm{ME}_{\mathrm{m}}$ and $\mathrm{NE}_{\mathrm{m}}$ estimated from the linear relationship were 594 and $386 \mathrm{~kJ} / \mathrm{kg}$ of body weight $(\mathrm{BW})^{0.75} / \mathrm{d}$ in the ICM, and 618 and $404 \mathrm{~kJ} / \mathrm{kg}$ of BW $\mathrm{d.75} / \mathrm{d}$ in the CSM, respectively. The $\mathrm{ME}_{\mathrm{m}}$ and $\mathrm{NE}_{\mathrm{m}}$ estimated by logarithmic regression were 607 and $448 \mathrm{~kJ} / \mathrm{kg}$ of BW.75 $/ \mathrm{d}$ in the ICM, and were 619 and $462 \mathrm{~kJ} / \mathrm{kg}$ of BW.75/d in the CSM, respectively.

Conclusion: The $\mathrm{NE}_{\mathrm{m}}$ values obtained in this study provide references for estimating the $\mathrm{NE}$ values of broiler diets.

Keywords: Broiler Maintenance Energy Requirement; Comparative Slaughter Method; Feed Intake; Heat Production; Indirect Calorimetry Method

\section{INTRODUCTION}

The net energy (NE) is assumed to represent the most accurate energy value of a feed [1]. The $\mathrm{NE}$ is usually partitioned into $\mathrm{NE}$ for maintenance $\left(\mathrm{NE}_{\mathrm{m}}\right)$ and production $\left(\mathrm{NE}_{\mathrm{p}}\right)$. Therefore, the determination of the $\mathrm{NE}$ value of a feed will be influenced by $\mathrm{NE}_{\mathrm{m}}$ evaluation. Fasting heat production (FHP), which represents the basal metabolic rate of animals, is usually used as a surrogate for $\mathrm{NE}_{\mathrm{m}}$ [2]. However, the determined FHP value may be affected by types (breed, age, sex, etc.) of animals, the length of the fasting period [3], and previous feeding conditions with a lower FHP at lower feed intake [4]. An alternative method to estimate $\mathrm{NE}_{\mathrm{m}}$ is to feed animals at several levels of feed intake to build the logarithmic regression between heat production (HP) and metabolizable energy intake (MEI) [5]. Then, the $\mathrm{NE}_{\mathrm{m}}$ can be calculated by extrapolating the $\mathrm{HP}$ to zero MEI from the logarithmic regression [6]. Furthermore, the metabolizable energy for maintenance $\left(\mathrm{ME}_{\mathrm{m}}\right)$ can be calculated by extrapolating the HP being equal to MEI. However, the traditional method for $\mathrm{ME}_{\mathrm{m}}$ is to use the linear relationship between retained energy (RE) and MEI [7]. The FHP (i.e., $\mathrm{NE}_{\mathrm{m}}$ ) can also be obtained from this linear regression. Moreover, the linear regression 
was used to calculate the $\mathrm{ME}_{\mathrm{m}}$ and the logarithmic regression was used to calculate $\mathrm{NE}_{\mathrm{m}}$ in some research, respectively $[8,9]$. However, the comparison of using logarithmic regression and linear regression to calculate both $\mathrm{ME}_{\mathrm{m}}$ and $\mathrm{NE}_{\mathrm{m}}$ are lacking. Furthermore, evaluations of the $\mathrm{NE}_{\mathrm{m}}$ in laying hens and broiler breeder pullets have been reported $[8,10,11]$. Similar research is scarce in broiler chickens.

The HP is frequently determined by the comparative slaughter method (CSM) [5,8]. Compared with the CSM, the indirect calorimetry method (ICM) is easily operated without killing animals and widely applied to HP determination for pigs. However, few studies have been done with the ICM for poultry, and no data can be found on the comparison of the two methods in HP determination. The objective of this study was to estimate the $\mathrm{NE}_{\mathrm{m}}$ in broilers using the CSM and ICM. The effect of regression model selection on $\mathrm{ME}_{\mathrm{m}}$ and $\mathrm{NE}_{\mathrm{m}}$ values was also compared.

\section{MATERIALS AND METHODS}

\section{Equipment}

Four open-circuit respiration chambers of approximately 0.43 $\mathrm{m}^{3}$ were used in this study based on a design similar to that of Van Milgen et al [12]. Briefly, the respiration chamber was air conditioned to maintain a constant temperature and humidity using an air conditioner and a heater. Gas was extracted continuously from the respiration chamber by a vacuum pump. Gas concentrations in each chamber were measured at 3-min intervals by an analyzer. The $\mathrm{O}_{2}$ was measured with a zirconium oxide sensor (Model 65-4-20; The Advanced Micro Instruments, Huntington Beach, CA, USA), whereas $\mathrm{CO}_{2}$ was measured with a nichtdispersiver infrarot sensor (AGM 10; Sensors Europe $\mathrm{GmbH}$, Erkrath, Germany) in the analyzer. The analyzer had a range of measurement of 0 to $25 \%$ for $\mathrm{O}_{2}$ and 0 to $2.5 \%$ for $\mathrm{CO}_{2}$.

\section{Experimental procedures}

The experimental procedures for animal trials were approved by the Animal Ethics Committee of the Chinese Academy of Agricultural Sciences and performed according to the guidelines for animal experiments set by the National Institute of Animal Health. The diet was based on corn, soybean meal, and casein (Table 1) and was formulated to meet the nutrient requirements of Arbor Acres (AA) broilers. The experiment employed a $2 \times 4$ factorial arrangement of treatments using the same diet. Factors were the evaluation method (ICM or CSM) and feed intake. Four levels of feed intake were calculated as $25 \%, 50 \%, 75 \%$, or $100 \%$ of the recommended ad libitum feed intake by the Arbor Acres Broiler Commercial Management Guide each day. In the ICM, 96 male AA broilers aged d 15 were used with 4 birds per replicate and 6 replicates in each feed intake treatment. In the CSM, 116 male AA birds aged d 15 were used. Among these 116 birds, 20 were selected for the initial data and 96 were assigned to 4 feed intake treatments with 6 replicate cages and 4 birds each.
Table 1. Ingredients and nutrient composition of diet

\begin{tabular}{lc}
\hline Items & Amount \\
\hline Ingredient (\%) & \\
Corn & 57.94 \\
Soybean meal & 26.12 \\
Casein & 6.96 \\
Soybean oil & 4.60 \\
Dicalcium phosphate & 2.11 \\
Limestone & 1.38 \\
Salt & 0.28 \\
DL-Methionine & 0.03 \\
Vitamin-mineral premix ${ }^{1)}$ & 0.50 \\
Choline & 0.08 \\
Calculated nutrient composition & \\
ME (MJ/kg) & 13.20 \\
Protein (\%) & 22.00 \\
Calcium (\%) & 1.00 \\
Total phosphorus (\%) & 0.68 \\
Available phosphorus (\%) & 0.46 \\
Methionine (\%) & 0.46 \\
Methionine+cysteine (\%) & 0.76 \\
Lysine (\%) & 1.31 \\
\hline
\end{tabular}

$\mathrm{ME}$, metabolizable energy.

1) Provided per kilogram of diet: vitamin $A, 12,500 \mathrm{IU}$; vitamin $D_{3}, 3,500 \mathrm{IU}$; vitamin $E$ (DL- $\alpha$-tocopheryl acetate), $20 \mathrm{IU}$; vitamin $\mathrm{K}_{3}, 3 \mathrm{mg}$; thiamine hydrochloride, $0.01 \mathrm{mg}$; riboflavin, $8.00 \mathrm{mg}$; pyridoxine hydrochloride, $4.5 \mathrm{mg}$; vitamin $\mathrm{B}_{12}, 0.02 \mathrm{mg}$; nicotinic acid, $34 \mathrm{mg}$; calcium pantothenate $12 \mathrm{mg}$; folic acid, $0.5 \mathrm{mg}$; biotin, $0.2 \mathrm{mg}$; Fe, $80 \mathrm{mg}$; $\mathrm{Cu}, 8 \mathrm{mg} ; \mathrm{Zn}, 80 \mathrm{mg} ; \mathrm{Mn}, 80 \mathrm{mg} ; \mathrm{l}, 0.7 \mathrm{mg}$; Se $0.3 \mathrm{mg}$.

All bird management was consistent with the recommendations of the Arbor Acres Broiler Commercial Management Guide.

\section{Indirect calorimetry method}

The measurements were conducted in 6 periods. In each of 6 measurement periods, 16 male birds were selected at approximately equal body weights (BWs) and randomly assigned into 4 respiration chambers at $d 14$, with 4 birds from one replicate of each feed intake treatment per respiration chamber, to acclimatize to the new environments with ad libitum access to diet and water. After $8 \mathrm{~h}$ of fasting being enforced by the withdrawal of feed [13], birds in each of 4 respiration chambers were weighed and were fed their respective level of feed intake at $\mathrm{d} 15$. The amounts of $\mathrm{O}_{2}$ consumption and $\mathrm{CO}_{2}$ production were determined from d 15 to 21 to calculate the HP, using the Brouwer [14] equation without correction for urinary nitrogen excretion. The respiration quotient (RQ) was determined as the volume of $\mathrm{CO}_{2}$ produced, divided by the volume of $\mathrm{O}_{2}$ consumed. Water was offered ad libitum at all times. Measurement was suspended for $2 \mathrm{~h}$ each day to replenish feed and to collect excreta. The collected excreta were pooled for each chamber over $5 \mathrm{~d}$, stored in a freezer, dried, and ground to pass through a $0.5-\mathrm{mm}$ screen. On d 21, birds were weighed to determine their weight gain and feed:gain.

\section{Comparative slaughter method}


After $8 \mathrm{~h}$ of fasting being enforced by the withdrawal of feed on $\mathrm{d} 15$, the birds were weighed. Twenty birds used as the initial slaughter group were euthanized by cervical dislocation, with their feathers being removed and weighed. Then, the feathers and carcasses were frozen $\left(-20^{\circ} \mathrm{C}\right)$. The remaining 96 birds were fed using the respective experimental feed intake until $\mathrm{d} 21$ when the birds were killed in the same way. The excreta from each cage were collected from $\mathrm{d} 15$ to 21 , pooled together, and processed as previously described. The frozen carcasses from the same replicate were first cut in small pieces, then mixed and ground with a meat grinder. Ground carcass samples were accurately weighed before and after freeze-drying to calculate the dry matter (DM) content and finely ground for further analyses. The pooled feathers were also ground for further analyses.

\section{Chemical analysis}

The gross energy (GE) content of diet, excreta, carcass, and feather samples from each evaluation method were determined in a bomb calorimeter (C2000, IKA, Guangzhou, China) using benzoic acid as a standard. The nitrogen content of carcasses and feathers were determined with a combustion analyzer (Dumatherm, Gerhardt, Germany) using ethylenediaminetetraacetic acid as a calibration standard, with crude protein being calculated by multiplying percentage $\mathrm{N}$ by a correction factor (6.25). The fat content was analyzed using the classical Soxhlet petroleumether extraction.

\section{Calculations}

For the ICM, the RE was calculated as the difference between the MEI and HP. For the CSM, the RE was calculated as the difference between final GE content of the total body ( $\mathrm{d} 21$ ) and initial GE content of the total body (d 15), and the HP was calculated as the difference between the MEI and RE. The MEI was calculated as follows:

$$
\operatorname{MEI}(\mathrm{kJ})=\mathrm{ME} \times \mathrm{FI} \text {, }
$$

where FI is the feed intake ( $\mathrm{kg}$ of $\mathrm{DM})$.

Energy retained as fat $\left(\mathrm{RE}_{\mathrm{f}}\right)$ and protein $\left(\mathrm{RE}_{\mathrm{p}}\right)$ were calculated as follows:

$$
\begin{aligned}
\mathrm{RE}_{\mathrm{f}}(\mathrm{kJ})= & {[\text { total body fat content d } 21(\mathrm{~g})} \\
& - \text { total body fat content d } 15(\mathrm{~g})] \times 38.2 \mathrm{~kJ} / \mathrm{g}, \\
\mathrm{RE}_{\mathrm{p}}(\mathrm{kJ})= & {[\text { total body protein content d } 21(\mathrm{~g})} \\
& - \text { total body protein content d } 15(\mathrm{~g})] \times 23.6 \mathrm{~kJ} / \mathrm{g},
\end{aligned}
$$

where the values of 38.2 and $23.6 \mathrm{~kJ} / \mathrm{g}$ are energy values per gram of fat and protein, respectively, and were according to Larbier and Leclercq [15].

The ME and NE of the diet were determined using the following equations:

$$
\begin{aligned}
& \mathrm{ME}(\mathrm{kJ} / \mathrm{kg} \text { of DM })=(\mathrm{GEI}-\mathrm{GEE}) / \mathrm{FI}, \\
& \mathrm{NE}(\mathrm{kJ} / \mathrm{kg} \text { of } \mathrm{DM})=(\mathrm{RE}+\mathrm{FHP}) / \mathrm{FI},
\end{aligned}
$$

where GEI is the gross energy intake ( $\mathrm{kJ} / \mathrm{kg}$ ), GEE is the gross energy output of excreta $(\mathrm{kJ} / \mathrm{kg})$, and FI is the feed intake $(\mathrm{kg}$ of $\mathrm{DM})$. The results for the MEI, RE, and HP were expressed as $\mathrm{kJ} / \mathrm{kg}$ of $\mathrm{BW}^{0.75} / \mathrm{d}$.

The relationship between the RE and MEI were calculated using the following linear regression [7]:

$$
\mathrm{RE}=\mathrm{a}+\mathrm{b} \times \mathrm{MEI} .
$$

The logarithmic relationship between the HP and MEI were calculated using the following regression [5]:

$$
\log (\mathrm{HP})=\log (\mathrm{a})+\mathrm{b} \times \mathrm{MEI},
$$

where $\mathrm{a}$ is the FHP $\left(\mathrm{kJ} / \mathrm{kg}\right.$ of $\left.\mathrm{BW}^{0.75}\right)$, and $\mathrm{b}$ is constant.

\section{Statistical analyses}

The $\mathrm{O}_{2}$ consumption, $\mathrm{CO}_{2}$ production, and $\mathrm{RQ}$ data measured by the ICM and $\mathrm{RE}_{\mathrm{f}}$ and $\mathrm{RE}_{\mathrm{p}}$ by the CSM were analyzed by oneway analysis of variance (ANOVA) of SPSS 19.0 (2010, SPSS Inc., Chicago, IL, USA). All other data were analyzed by two-way ANOVA as a $2 \times 4$ factorial arrangement of treatments using the general linear model procedure of SPSS to test the main effects of the evaluation method, the feed intake, and their interaction. Differences among treatment means were determined using a Duncan's means comparison when the significance of the factor was $\mathrm{p}<0.05$.

\section{RESULTS}

\section{Broiler growth performance}

The growth performance of broilers is presented in Table 2. There was no evaluation method and feed intake interaction for growth performance. Feed intake had significant effects on final BW, BW gain, and feed:gain $(p<0.01)$. Feed:gain increased $(p<0.01)$ as the feed intake decreased, except that of the treatment of $25 \%$ of ad libitum feed intake. Birds fed 25\% of ad libitum feed intake had negative BW gain and feed:gain.

\section{Energy value of the diet and energy balance of broilers}

Table 3 shows the data on the dietary energy values and energy balance of broilers. The evaluation method did not detect any differences in the ME, NE, and NE:ME of diet, and in the MEI, HP, and RE of broilers. The ME of the diet in the treatment of $25 \%$ of ad libitum feed intake was higher $(\mathrm{p}<0.01)$ than that in birds fed $100 \%$ of ad libitum feed intake. The dietary NE and NE:ME in the treatment of $100 \%$ of ad libitum feed intake were lower $(p<0.01)$ than these values in the other three treatments. 
Table 2. Effect of the evaluation method and feed intake on the performance of broilers

\begin{tabular}{|c|c|c|c|c|c|c|c|c|c|c|}
\hline \multirow{2}{*}{ Items } & \multicolumn{4}{|c|}{ Feed intake, $\%$ of ad libitum } & \multicolumn{2}{|c|}{ Evaluation method } & \multirow{2}{*}{ SEM } & \multicolumn{3}{|c|}{$\mathrm{p}$-value } \\
\hline & 25 & 50 & 75 & 100 & ICM & CSM & & EM & $\mathrm{FI}$ & $\mathrm{EM} \times \mathrm{FI}$ \\
\hline Initial BW (g/bird) & 513 & 517 & 514 & 517 & 514 & 517 & 1.47 & 0.354 & 0.658 & 0.127 \\
\hline Final BW (g/bird) & $497^{d}$ & $634^{c}$ & $721^{b}$ & $818^{\mathrm{a}}$ & 668 & 667 & 17.32 & 0.894 & $<0.001$ & 0.115 \\
\hline BW gain (g/bird) & $-16^{d}$ & $117^{c}$ & $206^{b}$ & $301^{\mathrm{a}}$ & 154 & 151 & 17.14 & 0.425 & $<0.001$ & 0.498 \\
\hline Feed intake (g/bird) & $118^{d}$ & $238^{c}$ & $356^{b}$ & $475^{\mathrm{a}}$ & 296 & 297 & 19.39 & 0.113 & $<0.001$ & 0.288 \\
\hline Feed:gain (g/g) & - & $2.06^{\mathrm{a}}$ & $1.73^{b}$ & $1.58^{b}$ & 1.78 & 1.80 & 0.045 & 0.812 & $<0.001$ & 0.816 \\
\hline
\end{tabular}

ICM, indirect calorimetry method; CSM, comparative slaughter method; SEM, standard error of the mean; EM, evaluation method; Fl, feed intake; BW, body weight.

${ }^{a-d}$ Means within a row lacking a common superscript differ $(p<0.05)$.

Table 3. Effect of the evaluation method and feed intake on the dietary energy values and energy balance of broilers

\begin{tabular}{|c|c|c|c|c|c|c|c|c|c|c|}
\hline \multirow{2}{*}{ Items } & \multicolumn{4}{|c|}{ Feed intake, $\%$ of ad libitum } & \multicolumn{2}{|c|}{ Evaluation method } & \multirow{2}{*}{ SEM } & \multicolumn{3}{|c|}{ p-value } \\
\hline & 25 & 50 & 75 & 100 & ICM & CSM & & EM & $\mathrm{FI}$ & $\mathrm{EM} \times \mathrm{FI}$ \\
\hline \multicolumn{11}{|l|}{ Energy value } \\
\hline ME (MJ/kg DM) & $15.77^{\mathrm{a}}$ & $15.69^{\mathrm{ab}}$ & $15.70^{\mathrm{ab}}$ & $15.46^{b}$ & 15.68 & 15.63 & 0.42 & 0.552 & 0.064 & 0.928 \\
\hline NE (MJ/kg DM) & $11.93^{\mathrm{a}}$ & $11.39^{\mathrm{a}}$ & $11.33^{\mathrm{a}}$ & $10.46^{b}$ & 11.25 & 11.30 & 0.12 & 0.795 & $<0.001$ & 0.948 \\
\hline NE:ME (\%) & $75.7^{\mathrm{a}}$ & $72.6^{\mathrm{a}}$ & $72.1^{\mathrm{a}}$ & $67.7^{b}$ & 71.7 & 72.3 & 0.72 & 0.624 & 0.001 & 0.917 \\
\hline \multicolumn{11}{|l|}{ Energy balance } \\
\hline MEl $\left(\mathrm{kJ} / \mathrm{kg}\right.$ of $\left.B W^{0.75} / \mathrm{d}\right)$ & $468^{d}$ & $850^{c}$ & $1,210^{b}$ & $1,498^{\mathrm{a}}$ & 1,009 & 1,004 & 56.44 & 0.454 & $<0.001$ & 0.380 \\
\hline $\mathrm{HP}\left(\mathrm{kJ} / \mathrm{kg}\right.$ of $\left.\mathrm{BW}^{0.75} / \mathrm{d}\right)$ & $569^{d}$ & $688^{c}$ & $792^{b}$ & $939^{a}$ & 744 & 751 & 20.63 & 0.568 & $<0.001$ & 0.819 \\
\hline $\operatorname{RE}\left(\mathrm{kJ} / \mathrm{kg}\right.$ of $\left.\mathrm{BW} W^{0.75} / \mathrm{d}\right)$ & $-101^{d}$ & $162^{c}$ & $418^{b}$ & $559^{\mathrm{a}}$ & 265 & 254 & 37.20 & 0.356 & $<0.001$ & 0.627 \\
\hline
\end{tabular}

ICM, indirect calorimetry method; CSM, comparative slaughter method; SEM, standard error of the mean; EM, evaluation method; Fl, feed intake; ME, metabolizable energy; DM, dry matter; $\mathrm{NE}$, net energy; MEI, metabolizable energy intake; $\mathrm{HP}$, heat production; RE, retained energy.

${ }^{a-d}$ Means within a row lacking a common superscript differ $(p<0.05)$.

The MEI, HP, and RE of broilers decreased $(\mathrm{p}<0.01)$ as the feed intake decreased. No evaluation method $\times$ feed intake interaction was observed on these parameters.

As presented in Table 4, the $\mathrm{O}_{2}$ consumption and $\mathrm{CO}_{2}$ production measured by ICM decreased $(\mathrm{p}<0.01)$ as the feed intake decreased. The RQ decreased $(\mathrm{p}<0.01)$ from 0.97 to 0.73 with the level of feed intake reducing from $100 \%$ to $25 \%$. Similarly, energy retained as fat and protein measured by the CSM decreased $(\mathrm{p}<0.01)$ as the feed intake decreased.

\section{Energy requirement for maintenance}

The linear regression equations between the RE and MEI, and the logarithmic regression equations between the HP and MEI are shown in Figure 1 to 4 . The values of $\mathrm{ME}_{\mathrm{m}}, \mathrm{NE}_{\mathrm{m}}$, and $\mathrm{K}_{\mathrm{m}}$ are shown in Table 5. From the linear regression equations (Equations 1 and 3), the $\mathrm{ME}_{\mathrm{m}}$, which was calculated by extrapolating the MEI to zero energy retention, was $594 \mathrm{~kJ} / \mathrm{kg}$ of $\mathrm{BW}^{0.75} / \mathrm{d}$ in the ICM and $618 \mathrm{~kJ} / \mathrm{kg}$ of BW $0.75 / \mathrm{d}$ in the CSM, and the $\mathrm{NE}_{\mathrm{m}} \mathrm{cal}-$ culated as the intercept on the $\mathrm{Y}$-axis of the linear regression equation was $386 \mathrm{~kJ} / \mathrm{kg}$ of BW $\mathrm{BW}^{0.75} / \mathrm{d}$ in the ICM and $404 \mathrm{~kJ} / \mathrm{kg}$ of $\mathrm{BW}^{0.75} / \mathrm{d}$ in the CSM. The $\mathrm{K}_{\mathrm{m}}$, calculated as the ratio between $\mathrm{NE}_{\mathrm{m}}$ and $\mathrm{ME}_{\mathrm{m}}$, was $65.0 \%$ in the ICM and $65.4 \%$ in the CSM. From the logarithmic regression equations (Equations 2 and 4), the calculated $\mathrm{ME}_{\mathrm{m}}$ was $607 \mathrm{~kJ} / \mathrm{kg}$ of $\mathrm{BW}^{0.75} / \mathrm{d}$ in the ICM and $619 \mathrm{~kJ} / \mathrm{kg}$ of BW${ }^{0.75} / \mathrm{d}$ in the CSM, and the $\mathrm{NE}_{\mathrm{m}}$ calculated by extrapolating the HP to zero MEI was $448 \mathrm{~kJ} / \mathrm{kg}$ of $\mathrm{BW}^{0.75} / \mathrm{d}$

Table 4. Effect of feed intake on $\mathrm{O}_{2}$ consumption, $\mathrm{CO}_{2}$ production, and $\mathrm{RQ}$ measured by the ICM, and retained energy as fat and protein by the CSM of broilers

\begin{tabular}{|c|c|c|c|c|c|c|}
\hline \multirow{2}{*}{ Items } & \multicolumn{4}{|c|}{ Feed intake, $\%$ of ad libitum } & \multirow{2}{*}{ SEM } & \multirow{2}{*}{ p-value } \\
\hline & 25 & 50 & 75 & 100 & & \\
\hline \multicolumn{7}{|l|}{ ICM } \\
\hline$V \mathrm{CO}_{2}\left(\mathrm{~L} / \mathrm{kg}\right.$ of $\left.\mathrm{BW}^{0.75} / \mathrm{d}\right)$ & $20.79^{d}$ & $27.99^{c}$ & $32.69^{b}$ & $43.38^{\mathrm{a}}$ & 1.74 & $<0.001$ \\
\hline $\mathrm{RQ}$ & $0.73^{d}$ & $0.84^{c}$ & $0.85^{b}$ & $0.97^{\mathrm{a}}$ & 0.02 & $<0.001$ \\
\hline \multicolumn{7}{|l|}{ CSM } \\
\hline
\end{tabular}

$\mathrm{RQ}$, respiratory quotient $\left(\mathrm{CO}_{2} / \mathrm{O}_{2}\right) ; \mathrm{ICM}$, indirect calorimetry method; $\mathrm{CSM}$, comparative slaughter method; $\mathrm{V} \mathrm{O}_{2}$, volume of oxygen consumption; $\mathrm{V} \mathrm{CO}_{2}$, volume of carbon dioxide production; $R E_{f}$ retained energy as fat; $R E_{p}$, retained energy as protein.

${ }^{a-d}$ Means within a row lacking a common superscript differ $(p<0.05)$. 


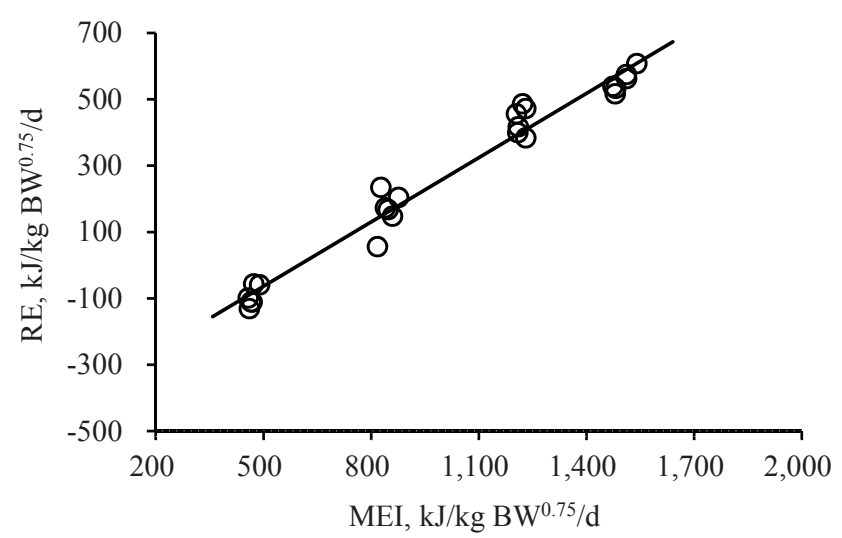

Figure 1. The relationship between the retained energy (RE) and metabolizable energy intake (MEI) of broilers in the indirect calorimetry method. $\mathrm{RE}=$ $-386+0.65 \times \mathrm{MEl} ; \mathrm{R}^{2}=0.97, \mathrm{p}<0.001$.

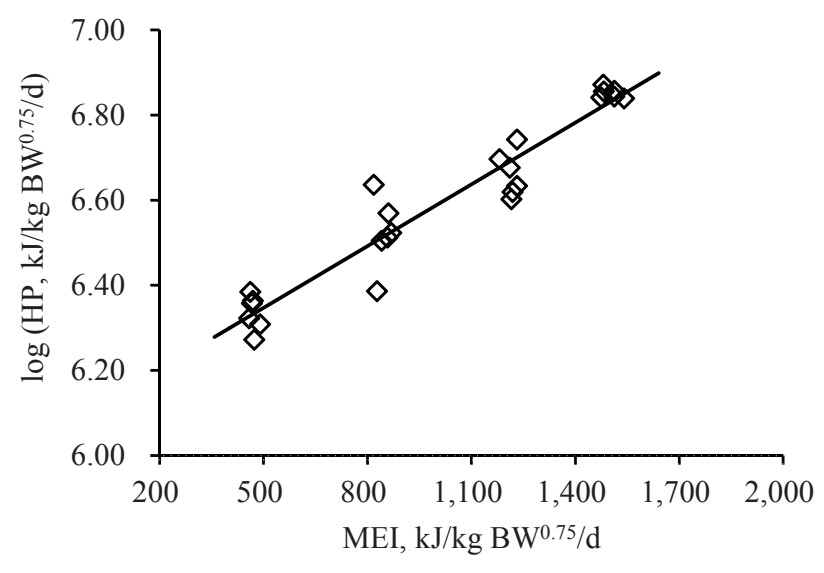

Figure 2. The relationship between the logarithm of heat production (HP) and metabolizable energy intake (MEI) of broilers in the indirect calorimetry method. log $(H P)=6.11+\left(4.83 \times 10^{-4}\right) \times M E l ; R^{2}=0.92, p<0.001$.

in the ICM and $462 \mathrm{~kJ} / \mathrm{kg}$ of $\mathrm{BW}^{0.75} / \mathrm{d}$ in the CSM. The $\mathrm{K}_{\mathrm{m}}$ was $73.8 \%$ in the ICM and $75.0 \%$ in the CSM.

\section{DISCUSSION}

\section{Broiler growth performance}

The birds fed lower feed intakes had poorer growth performance [16]. However, the growth performance in the same feed intake was not affected by the evaluation method, which indicated that

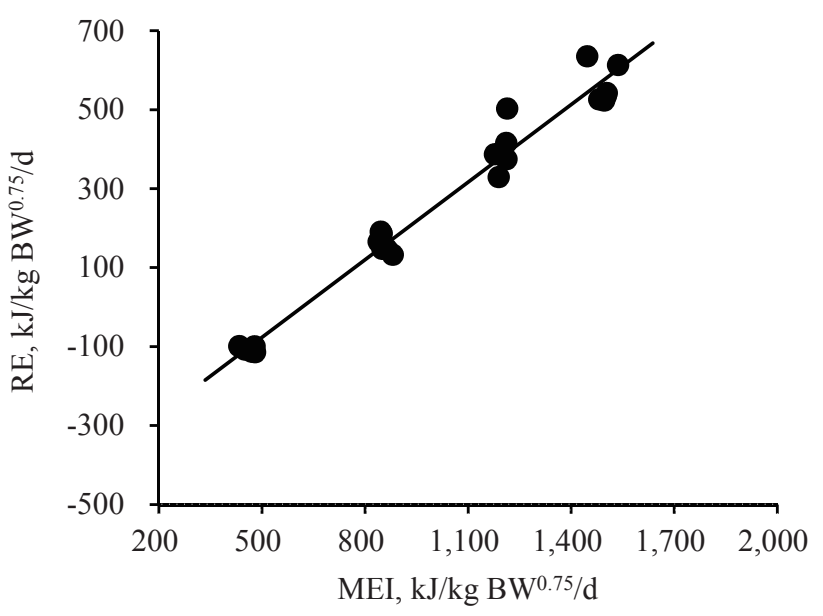

Figure 3. The relationship between the retained energy (RE) and metabolizable energy intake (MEI) of broilers in the comparative slaughter method. RE = $-404+0.63 \times \mathrm{MEl} ; R^{2}=0.97, p<0.001$.

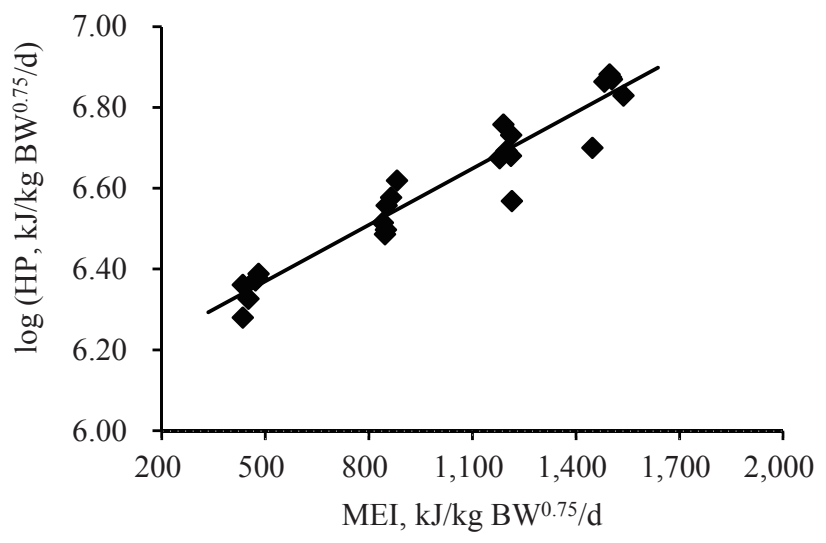

Figure 4. The relationship between the logarithm of heat production (HP) and metabolizable energy intake (MEI) of broilers in the comparative slaughter method. $\log (H P)=6.14+\left(4.65 \times 10^{-4}\right) \times M E l ; R^{2}=0.93, p<0.001$.

the respiration chambers could provide a similar growth environment as that in the CSM for broilers. Birds fed $25 \%$ of ad libitum feed intake had negative BW gain and feed:gain. It has been suggested that when the MEI is below the maintenance requirement, the energy used by broilers will not only be supplied by their diet, but also by their body reserves [6].

Table 5. Regression of the RE and logarithm of the HP as a function of the MEl, values of $\mathrm{ME}_{\mathrm{m},}, \mathrm{NE}_{\mathrm{m}}$, and $\mathrm{K}_{\mathrm{m}}$ of broilers

\begin{tabular}{|c|c|c|c|c|c|}
\hline Method & Equation number & Regression equations & $\begin{array}{c}\mathrm{ME}_{\mathrm{m}} \\
\left(\mathrm{kJ} / \mathrm{kg} \text { of } \mathrm{BW}^{0.75} / \mathrm{d}\right)\end{array}$ & $\begin{array}{c}\mathrm{NE}_{\mathrm{m}} \\
\left(\mathrm{kJ} / \mathrm{kg} \text { of } \mathrm{BW}^{0.75} / \mathrm{d}\right)\end{array}$ & $\mathrm{K}_{\mathrm{m}}(\%)$ \\
\hline $\mathrm{ICM}$ & 1 & $\mathrm{RE}=-386+0.65 \times \mathrm{MEI}$ & 594 & 386 & 65.0 \\
\hline $\mathrm{ICM}$ & 2 & $\log (H P)=6.11+\left(4.83 \times 10^{-4}\right) \times$ MEI & 607 & 448 & 73.8 \\
\hline CSM & 3 & $\mathrm{RE}=-404+0.63 \times \mathrm{MEI}$ & 618 & 404 & 65.4 \\
\hline CSM & 4 & $\log (H P)=6.14+\left(4.65 \times 10^{-4}\right) \times \mathrm{MEI}$ & 619 & 462 & 75.0 \\
\hline
\end{tabular}

$\mathrm{RE}$, retained energy; $\mathrm{HP}$, heat production; $\mathrm{MEl}$, metabolizable energy intake; $\mathrm{ME}_{\mathrm{m},}$, metabolizable requirement for maintenance; $\mathrm{NE}_{\mathrm{m},}$, net energy requirement for maintenance; $\mathrm{K}_{\mathrm{m},}$ the ratio between $\mathrm{NE}_{\mathrm{m}}$ and $\mathrm{ME}_{\mathrm{m}} ; \mathrm{ICM}$, indirect calorimetry method; $\mathrm{CSM}$, comparative slaughter method. 
Energy value of the diet and energy balance of broilers The ME content of diet was not affected by feed intake when the level of feed intake was more than $50 \%$ of ad libitum, which is in agreement with the observation reported by Hill and Anderson [17]. The increased dietary ME content at the lowest feed intake level might be ascribed to the change in the metabolic and endogenous energy losses of broilers. The determined feed NE increased as the feed intake decreased. The dietary NE value is usually calculated as the sum of the FHP (i.e., $\mathrm{NE}_{\mathrm{m}}$ ) and RE [18]. Therefore, the increased NE value in a lower feed intake may be supported by previous observations that feed intake affects the FHP [4]. The dietary NE:ME in 100\% of the ad libitum feed intake group was $67.7 \%$, which was lower than the mean NE:ME value (76.4\%) observed by Carré and Juin [19] and 70.5\% observed by Yang et al [20]. This could be associated with the differences in the diet composition and types (breed, age, sex, etc.) of poultry. The NE:ME of diet increased as the feed intake decreased, which means that the proportion of ME transformed into heat increment decreased as the feed intake decreased. This may be another reason for the higher NE value in the lower feed intake group.

According to De Lange et al [21], the MEI is partitioned into the thermal effect of feeding $\left(\mathrm{HP}_{\mathrm{f}}\right)$, activity $\mathrm{HP}\left(\mathrm{HP}_{\mathrm{a}}\right)$, plateau fasting $\mathrm{HP}\left(\mathrm{FHP}_{\mathrm{p}}\right)$, and RE. Therefore, the reduction of the $\mathrm{HP}_{\mathrm{f}}$ and $\mathrm{RE}$ that accompanies a reduction in the MEI may result in the reduction of the HP. Energy retained as protein was positive and as fat was negative in $25 \%$ of the ad libitum feed intake group measured by the CSM, which means that broilers can deposit protein by expending body lipid at a lower MEI $[22,23]$. On the another hand, the RQ for broilers receiving $25 \%$ of ad libitum feed intake measured by the ICM dropped to 0.73 , which also indicated that broilers utilized body fat deposits to maintain energy metabolism [24].

\section{Energy requirement for maintenance}

The traditional method for estimating the $\mathrm{ME}_{\mathrm{m}}$ requirement is to use the linear relationship between the RE and MEI by extrapolating to the MEI at zero energy retention (i.e., the intercept on the $\mathrm{X}$-axis) $[7,9]$. Furthermore, when the MEI is equal to zero, the intercept on the $\mathrm{Y}$-axis of this equation represents the FHP (i.e., $\mathrm{NE}_{\mathrm{m}}$ ) [7]. According to this method, the estimated $\mathrm{ME}_{\mathrm{m}}$ values were $594 \mathrm{~kJ} / \mathrm{kg}$ of BW $\mathrm{BW}^{0.75} / \mathrm{d}$ in the ICM and $618 \mathrm{~kJ} / \mathrm{kg}$ of $\mathrm{BW}^{0.75} / \mathrm{d}$ in the CSM. The $\mathrm{ME}_{\mathrm{m}}$ values determined herein are similar to the value $\left(602 \mathrm{~kJ} / \mathrm{kg}\right.$ of $\left.\mathrm{BW}^{0.75} / \mathrm{d}\right)$ determined from broiler breeder pullets ( 4 wks of age) by Sakomura et al [8] at $22^{\circ} \mathrm{C}$, and were in the ranges of values estimated by Nieto et al [25] for male broiler chickens (519 to $628 \mathrm{~kJ} / \mathrm{kg}$ of BW ${ }^{0.75} / \mathrm{d}$ ). The $\mathrm{NE}_{\mathrm{m}}$ data for broilers calculated from linear regression are limited. The $\mathrm{NE}_{\mathrm{m}}$ values of $386 \mathrm{~kJ} / \mathrm{kg}$ of $\mathrm{BW}^{0.75} / \mathrm{d}$ in the ICM and 404 $\mathrm{kJ} / \mathrm{kg}$ of BW ${ }^{0.75} / \mathrm{d}$ in the CSM were in agreement with the values of 395 and $387 \mathrm{~kJ} / \mathrm{kg}$ of $\mathrm{BW}^{0.75} / \mathrm{d}$ for two breeds of laying hens measured by the same method [7].
The logarithmic relationship between the HP and MEI is usually used to calculate the $\mathrm{NE}_{\mathrm{m}}$ as being the $\mathrm{HP}$ at zero MEI $[5,26]$. Similarly, the $\mathrm{ME}_{\mathrm{m}}$ can also be calculated by extrapolating the HP being equal to the MEI. In the current study, the estimated $\mathrm{ME}_{\mathrm{m}}$ values obtained by logarithmic regression were $607 \mathrm{~kJ} / \mathrm{kg}$ of $\mathrm{BW}^{0.75} / \mathrm{d}$ in the ICM and $619 \mathrm{~kJ} / \mathrm{kg}$ of $\mathrm{BW}^{0.75} / \mathrm{d}$ in the CSM, which were nearly equal to the respective value calculated by linear regression. The $\mathrm{NE}_{\mathrm{m}}$ data for broilers calculated form logarithmic regression are also lacking. The $\mathrm{NE}_{\mathrm{m}}$ value obtained from logarithmic regression was $448 \mathrm{~kJ} / \mathrm{kg}$ of $\mathrm{BW}^{0.75} / \mathrm{d}$ in the ICM and $462 \mathrm{~kJ} / \mathrm{kg}$ of $\mathrm{BW}^{0.75} / \mathrm{d}$ in the CSM, which were greater than the $\mathrm{NE}_{\mathrm{m}}$ values calculated by linear regression in this study. The $\mathrm{NE}_{\mathrm{m}}$ values of $497.48,457.31$, and $387.02 \mathrm{~kJ} / \mathrm{kg} \mathrm{BW}^{0.75} / \mathrm{d}$ for broiler breeder pullets ( 4 wks of age) at $15^{\circ} \mathrm{C}, 22^{\circ} \mathrm{C}$, and $30^{\circ} \mathrm{C}$, and $418.57,334.09$, and $289.32 \mathrm{~kJ} / \mathrm{kg} \mathrm{BW}{ }^{0.75} / \mathrm{d}$ for laying hens (2 wks of age) at $12^{\circ} \mathrm{C}, 22^{\circ} \mathrm{C}$, and $31^{\circ} \mathrm{C}$ were determined with logarithmic regression between the HP and MEI by Sakomura et al $[8,11]$. Moreover, the $\mathrm{NE}_{\mathrm{m}}$ can also be estimated by direct measurements of the FHP in fasting animals [27]. O'Neill and Jackson [10] founded that the FHP varied between 404 and 464 $\mathrm{kJ} / \mathrm{kg} \mathrm{BW}{ }^{0.75} / \mathrm{d}$ for hens and between 223 and $349 \mathrm{~kJ} / \mathrm{kg} \mathrm{BW}{ }^{0.75} / \mathrm{d}$ for the cockerels. Furthermore, Noblet et al [2] suggested that the present FHP values measured in modern lines of broilers should be expressed as per $\mathrm{kg}$ of $\mathrm{BW}^{0.70}$, and the FHP values in 0.5 to $3.0 \mathrm{~kg}$ broilers ranged between 410 and $460 \mathrm{~kJ} / \mathrm{kg} \mathrm{BW}^{0.70} / \mathrm{d}$. These results suggest that the estimates of $\mathrm{NE}_{\mathrm{m}}$ are affected by types (breed, age, sex, etc.) of animals, the experimental environment, and measurement methods. Within one animal species, the constant FHP can be obtained by being expressed as per unit of metabolic BW after the exponent of metabolic BW being calculated for an animal over a large BW. Noblet et al [2] indicated that the FHP was linearly related to the $\mathrm{BW}^{0.70}$. In our previous study, the exponent of metabolic BW was 0.74 for AA broilers weighing 0.94 to $2.75 \mathrm{~kg}$, and the FHP per $\mathrm{kg}$ of $\mathrm{BW}^{0.74}$ were constant for broilers in this BW range [28]. Therefore, the respective $\mathrm{NE}_{\mathrm{m}}$ values of different types (breed, sex, etc.) of animals should be determined in standardized condition to calculate the NE content of a feed ingredient. The NE value of a poultry diet should express the energy cost of production (growth, egg, etc.) and $\mathrm{NE}_{\mathrm{m}}$. The $\mathrm{K}_{\mathrm{m}}$ values of $73.8 \%$ from the ICM and $75.0 \%$ from the CSM calculated by logarithmic regression were higher than the values of $65.0 \%$ from the ICM and $65.4 \%$ from the CSM obtained by linear regression, which was caused by the lower $\mathrm{NE}_{\mathrm{m}}$ values determined by linear regression. The $\mathrm{K}_{\mathrm{m}}$ values determined in the present experiment from logarithmic regression are similar to those estimated by Sakomura et al $[8,9]$ for broiler breeder pullets $\left(75 \%, 76 \%\right.$, and $72 \%$ at $15^{\circ} \mathrm{C}, 22^{\circ} \mathrm{C}$, and $30^{\circ} \mathrm{C}$, respectively) and for broiler chickens $(76 \%, 80 \%$, and $76 \%$ at $13^{\circ} \mathrm{C}, 23^{\circ} \mathrm{C}$, and $32^{\circ} \mathrm{C}$, respectively), in which the $\mathrm{NE}_{\mathrm{m}}$ values were calculated by logarithmic regression between the HP and MEI and the $\mathrm{ME}_{\mathrm{m}}$ values were calculated by the linear relationship between the RE and MEI, respectively. Balnave [29] indicated 
that the variability in the efficiency for maintenance ranged between $66 \%$ and $78 \%$. This variability in efficiencies of energy utilization for maintenance could be related with the composition of the diets [25].

In conclusion, the $\mathrm{ME}_{\mathrm{m}}$ and $\mathrm{NE}_{\mathrm{m}}$ estimated from the linear relationship between the RE and MEI were 594 and $386 \mathrm{~kJ} / \mathrm{kg}$ of $\mathrm{BW}^{0.75} / \mathrm{d}$ in the ICM, and those in the CSM were 618 and $404 \mathrm{~kJ} / \mathrm{kg}$ of $\mathrm{BW}^{0.75} / \mathrm{d}$. The $\mathrm{ME}_{\mathrm{m}}$ and $\mathrm{NE}_{\mathrm{m}}$ estimated by logarithmic regression between the HP and MEI were 607 and 448 $\mathrm{kJ} / \mathrm{kg}$ of $\mathrm{BW}^{0.75} / \mathrm{d}$ in the ICM, and those in the CSM were 619 and $462 \mathrm{~kJ} / \mathrm{kg}$ of $\mathrm{BW}^{0.75} / \mathrm{d}$. These results provide references for the determination of $\mathrm{NE}$ values of broiler feed ingredients.

\section{CONFLICT OF INTEREST}

We certify that there is no conflict of interest with any financial organization regarding the material discussed in the manuscript.

\section{ACKNOWLEDGMENTS}

This work was supported by the China Agricultural Research System (CARS-42) and the National Key Technology Support Program (2012BAD51G02).

\section{REFERENCES}

1. Noblet J. Recent developments in net energy research for swine. Adv Pork Prod 2007;18:149-56.

2. Noblet J, Dubois S, Lasnier J, et al. Fasting heat production and metabolic BW in group-housed broilers. Animal 2015;9:1138-44.

3. Ning D, Yuan JM, Wang YW, Peng YZ, Guo YM. The net energy values of corn, dried distillers grains with solubles and wheat bran for laying hens using indirect calorimetry method. Asian-Australas J Anim Sci 2014;27:209-16.

4. Labussière E, van Milgen J, de Lange CF, Noblet J. Maintenance energy requirements of growing pigs and calves are influenced by feeding level. J Nutr 2011;141:1855-61.

5. Lofgreen GP, Garrett WN. A system for expressing net energy requirements and feed values for growing and finishing beef cattle. J Anim Sci 1968;27:793-806.

6. Van Milgen J, Noblet J. Partitioning of energy intake to heat, protein, and fat in growing pigs. J Anim Sci. 2003;81(14 suppl 2):E86-93.

7. Farrel DJ. General principles and assumptions of calorimetry. In: Morris TR, Freeman BM. editors. Energy requirements of poultry. Edinburgh, UK: British Poultry Science; 1974. p. 1-23.

8. Sakomura NK, Silva R, Couto HP, Coon C, Pacheco CR. Modeling metabolizable energy utilization in broiler breeder pullets. Poult Sci 2003;82:419-27.

9. Sakomura NK, Longo FA, Oviedo-Rondon EO, Boa-Viagem C, Ferraudo A. Modeling energy utilization and growth parameter description for broiler chickens. Poult Sci 2005;84:1363-69.

10. O'Neill SJB, Jackson N. The heat production of hens and cockerels maintained for an extended period of time at a constant environmental temperature of $23^{\circ} \mathrm{C}$. J Agric Sci 1974;82:549-52.

11. Sakomura NK, Basaglia R, Sá-Fortes CML, Fernandes JBK. Model for metabolizable energy requirements of laying hens. R Bras Zootec 2005;34:575-83.

12. Van Milgen J, Noblet J, Dubois S, Bernier JF. Dynamic aspects of oxygen consumption and carbon dioxide production in swine. $\mathrm{Br}$ J Nutr 1997;78:397-410.

13. Barekatain MR, Noblet J, Wu SB, Iji PA, Choct M, Swick RA. Effect of sorghum distillers dried grains with solubles and microbial enzymes on metabolizable and net energy values of broiler diets. Poult Sci 2014;93:2793-801.

14. Brouwer E. Report of sub-committee on constants and factors. In: Blaxter KL, editor. Energy metabolism. London, UK: EAAP Publication. No. 11. Academic Press; 1965. p. 441-443.

15. Larbier M, Leclercq B. Energy metabolism. In: Wiseman J, editor. Nutrition and Feeding of Poultry. Nottingham, UK: Nottingham University Press; 1992. p. 47-73.

16. Swatson HK, Gous R, Iji PA, Zarrinkalam R. Effect of dietary protein level, amino acid balance and feeding level on growth, gastrointestinal tract, and mucosal structure of the small intestine in broiler chickens. Anim Res 2002;51:501-15.

17. Hill FW, Anderson DL. Comparison of metabolizable energy and productive energy determinations with growing chicks. J Nutr 1958; 64:587-603.

18. Noblet J, Fortune H, Shi XS, Dubois S. Prediction of net energy value of feeds for growing pigs. J Anim Sci 1994;72:344-54.

19. Carré B, Juin H. Partition of metabolizable energy, and prediction of growth performance and lipid deposition in broiler chickens. Poult Sci 2015;94:1287-97.

20. Yang Y, Iji PA, Kocher A, et al. Effects of mannanoligosaccharide in broiler chicken diets on growth performance, energy utilisation, nutrient digestibility and intestinal microflora. Br Poult Sci 2008;49: 186-94.

21. De Lange K, van Milgen J, Noblet J, Dubois S, Birkett S. Previous feeding level influences plateau heat production following a $24 \mathrm{~h}$ fast in growing pigs. Br J Nutr 2006;95:1082-7.

22. Close WH, Mount LE, Brown D. The effects of plane of nutrition and environmental temperature on the energy metabolism of the growing pig. 2. Growth rate, including protein and fat deposition. Br J Nutr 1978;40:423-31.

23. Quiniou N, Noblet J, Van Milgen J, Dourmad JY. Effect of energy intake on performance, nutrient and tissue gain and protein and energy utilization in growing boars. Anim Sci 1995;61:133-43.

24. MacLeod MG, Lundy H, Jewitt TR. Heat production by the mature male turkey (Meleagris gallopavo): Preliminary measurements in an automated, indirect, open-circuit multi-calorimeter system. $\mathrm{Br}$ Poult Sci 1985;26:325-33.

25. Nieto R, Prieto C, Fernandez-Figares I, Aguilera JF. Effect of dietary protein quality on energy metabolism in growing chickens. Br J Nutr 1995;74:163-72.

26. Chizzotti ML, Valadares Filho SC, Tedeschi LO, Chizzotti FH, Carstens 
GE. Energy and protein requirements for growth and maintenance of F1 Nellore×Red Angus bulls, steers, and heifers. J Anim Sci 2007; 85:1971-81.

27. Noblet J, Van Milgen J, Dubois S. Utilisation of metabolisable energy of feeds in pigs and poultry: interest of net energy systems? In: Proceedings of the 21st Annual Australian Poultry Science Sumposium; 1-3rd February 2010; New South Wales, Sydney. pp. 26-35.
28. Liu W, Cai H, Yan H, et al. Effects of body weight on total heat production and fasting heat production in net energy evaluation of broilers. Chinese J Anim Nutr 2014;26:2118-25.

29. Balnave D. Biological factors affecting energy expenditure. In: Morris TR, Freeman BM, editors. Energy Requirements of Poultry. Edinburgh, UK: British Poultry Science Ltd; 1974. pp. 25-46. 